\title{
Conformational flexibility and pseudosymmetric aggregation in a betainium salt hydrate
}

\author{
Kinga Roszak $^{1}$ - Andrzej Katrusiak ${ }^{1}$ (D) - Zofia Dega-Szafran ${ }^{1} \cdot$ Anna Komasa $^{1}$ • \\ Iwona Kowalczyk $^{1} \cdot$ Miroslaw Szafran $^{1}$
}

Received: 1 September 2016 / Accepted: 18 November 2016/Published online: 8 December 2016

(C) The Author(s) 2016. This article is published with open access at Springerlink.com

\begin{abstract}
The cation of 3-(trimethylammonium)-benzoic acid exhibits a considerable conformational flexibility connected to the orientation of carboxyl group, coupled to the proton position, and rotations of the trimethylammonium group. This conformational flexibility considerably affects the aggregation of ions and molecules of 3-(trimethylammonium)benzoic acid iodide hydrate, which crystallizes in a lowsymmetry structure with four symmetry-independent formula units (monoclinic space group $P c, Z^{\prime}=4$, model I). However this structure approximates the symmetry of space group $P 2_{1} /$ $c$ in the same unit cell ( $Z^{\prime}=2$, model II), and also even a still more highly symmetric structure of space group $P 2_{1} / c$ in a half-smaller unit cell ( $Z^{\prime}=1$, model III). The independent formula units are differentiated by the conformations of trimethylammonium groups (ordered in model I, but disordered in models II and III), conformations of the carboxyl groups and positions of $\mathrm{OH} \cdots \mathrm{O}$ bonded water molecules (ordered in molecules I and II, and disordered in model III), while the bulks of the cations and iodide anions are consistent for all models. While the calorimetric study and varied-temperature structural determinations exclude phase transitions of the highly pseudosymmetric model I. This pseudosymmetry is independent of temperature between $100 \mathrm{~K}$ and the m.p. at $463 \mathrm{~K}$, and illustrates subtle structural effects leading complex molecular aggregation in the crystal. Theoretical
\end{abstract}

Electronic supplementary material The online version of this article (doi:10.1007/s11224-016-0889-4) contains supplementary material, which is available to authorized users.

Andrzej Katrusiak

katran@amu.edu.pl

1 Faculty of Chemistry, Adam Mickiewicz University, Umultowska 89b, 61-614 Poznań, Poland computations confirm the low energy differences between the conformers.

Keywords Aggregation $\cdot$ Betainium salt $\cdot$ Hydrate $\cdot$ Crystal structure $\cdot$ Intermolecular interactions

\section{Introduction}

Zwitterions are compounds with oppositely charged centers and often referred to as betaines dipolar ions, salt-bridged containing molecules and inner salts. These species are exeptionally important in biological transformations, organic sythesis and preparation of novel materials of various applications in medicine, pharmacy and industry [1-3]. Zwitterions contain a quaternary nitrogen atom and a carboxylate group, separated by one or more carbon atoms. The ammonium group is inert as a hydrogen bond center, whereas the carboxylate group is basic $[4,5]$. At normal conditions betaines crystallize as hydrates, because of the strong $\mathrm{H}$-acceptor carboxylic group and no acidic $\mathrm{H}$-donors. The formation of hydrates is technologically important, however it generally cannot be always predicted [6-11]. The zwitterionic hydrates crystallize with one, two, three or more water molecules [11]. Being good proton-acceptors, dipolar ions form 1:1, 2:1 and 3:2 adducts with inorganic acids, which crystallize as anhydrous compounds or hydrates. In the 2:1 complex two zwitterions are bridged by the $\mathrm{H}$-atom, forming a homoconjugated cation with an inorganic anion as a counter ion. Most of the 2:1 complexes are anhydrous and only few of them crystallize as hydrates. The water molecule interacts with the anion [12-17]. In the $1: 1: \mathrm{H}_{2} \mathrm{O}$ complexes of zwitterions with inorganic acids, the carboxylate group is protonated and it forms $\mathrm{H}$-bonds $\mathrm{COOH} \cdots \mathrm{OH}_{2}$ to water molecules, which are further H-bonded to halogen anions [11, 18-24]. However, in the 
complex of betaine hydrogen selenate monohydrate the anion interacts both with the carboxylate group of the protonated betaine and water [25]. Moreover, there are some exceptions from the typical interactions described above. In 3hydroxypyridine betaine hydrochloride monohydrate the hydroxy substituent interacts with the water molecule, while the carboxylic group with the chloride anion, through the $\mathrm{OH}^{\cdots} \cdots$ $\mathrm{OH}_{2}$ and $\mathrm{COOH} \cdots \mathrm{Cl}^{-}$hydrogen bonds of $2.566(2)$ and 2.993(2) A, respectively [26]. In 4-amino-1-(2carboxyethyl)-pyridinium bromide hemihydrate two symmetry independent carbonyl groups are $\mathrm{H}$-bonded, one forming a centrosymmetric dimer and the second symmetryindependent group is $\mathrm{H}$-bonded to the water molecule. Hence the complex is built of $\mathrm{Br}^{-}-\mathrm{H}_{2} \mathrm{O}$ - cation $-\mathrm{Br}^{-}$cation - cation - $\mathrm{Br}^{-}$- cation $-\mathrm{H}_{2} \mathrm{O}-\mathrm{Br}^{-}$chain links [27]. The unusual water-betaine interactions are observed in 1 methylquinolinium-3-carboxylic chloride monohydrate, where the unit cell comprises six symmetry-independent complexes. In four of them the 1-methylquinolinium-3-carboxylic groups are $\mathrm{H}$-bonded to water molecules, while in two others the carboxylate groups are H-bonded to hydronium ions [28]. The complexes of betaines with acids display interesting physical properties, including phase transitions, ferroelectric, antiferroelectic and ferroelastic behavior, as well as commensurate and incommensurate phases [29-41].

An interesting group of zwitterionic compounds are benzbetaines, ortho-, meta- and para-trimethylammonium benzoates, and their esters, hydrates and salts with halogen anions [17, 42-51]. Quaternization of dimethylaminobenzoic acids by an excess methyl iodide in methanol depends on temperature and time of reaction [42]. In some condition the methyl group can transfer from the amino group to the carboxylic group to give an ester derivative $[42,51]$.

Recently, we reported two exceptionally similar polymorphs of a unique anhydrous [di-(3-trimethylammoniumbenzoic acid)-(3-trimethylammonium-benzoate)] diiodide 3:2 complex [52]. Presently, we have obtained a highly pseudosymmetric hydrate of 3-trimethylammonium-benzoic acid iodide (1) 1:1 complex, shown in Fig. 1, and we studied its structure by single-crystal X-ray diffraction in the temperature range of 130-296 K, by differential scanning calorimetry (DSC), thermogravimetry (TG), differential thermal analysis (DTA), FTIR spectroscopy and DFT calculations.

\section{Experimental section}

\section{Synthesis}

To a solution of $6 \mathrm{~g}(0.0365 \mathrm{~mol})$ of 3-dimethylamino-benzoic acid in $30 \mathrm{ml} \mathrm{CH}_{3} \mathrm{OH}, 5.7 \mathrm{~g}(0.040 \mathrm{~mol})$ of methyl iodide was added and stirred at $25{ }^{\circ} \mathrm{C}$ for $28 \mathrm{~h}$. The crude product was filtered off, washed with acetonitrile. Yellow crystals were

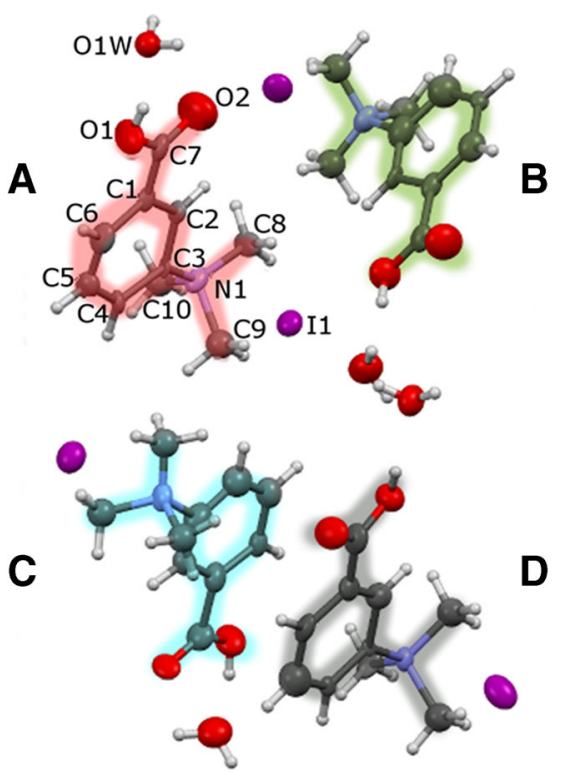

Fig. 1. The symmetry independent unit of 3-(trimethylammonium)benzoic acid iodide hydrate. Thermal ellipsoids have been drawn at the $50 \%$ probability level. Independent cations $A$ (atoms C1-C10), B (C11$\mathrm{C} 20), C(\mathrm{C} 21-\mathrm{C} 30)$ and $D(\mathrm{C} 31-\mathrm{C} 40)$ are highlighted red, green, blue, and gray, respectively (all atomic labels, of four independent molecules and including $\mathrm{H}$-atoms, are shown in Fig. S1, in Supplementary Material).

recrystallized from water, m.p. $189-194{ }^{\circ} \mathrm{C}$. Analysis for $\mathrm{C}_{10} \mathrm{H}_{14} \mathrm{NO}_{2} \cdot \mathrm{H}_{2} \mathrm{O}$, m.wt. 327.15. Calc.: \%C 36.94, \% $\mathrm{H}$ 4.96, \% N 4.31; Found: \%C 37.09, \%H 4.86, \%N 4.28.

\section{Measurements}

The crystals of 3-(trimethylammonium)-benzoic acid iodide hydrate, 1 , were obtained in the form of long plates, however their single-crystal quality was low. X-Ray diffraction data were measured using an Oxford Diffraction Excalibur EOS-CCD diffractometer, equipped with an EOS-CCD detector, with $\operatorname{MoK} \alpha$ radiation, and a Cryosystem low-temperature attachment. Single-crystal diffraction data were collected at the 130-296 K temperature range. The structure was solved by direct methods with program SHELXS and refined on $F^{2}$ by full-matrix least-squares with SHELXL [53]. The positions of $\mathrm{H}$ atoms in the cations were located from the molecular geometry and those in the water molecules were found from the difference Fourier maps and then the O-H distances were constrained in the refinement. The anisotropic thermal parameters were refined for the non- $\mathrm{H}$-atoms, some of them with constrains reducing their elongation, and isotropic $U_{\text {iso }}$ parameters for $\mathrm{H}$ atoms were linked to $U_{\text {eq }}$ of their carriers. The atomic labels of non-H atoms in independent cations $\boldsymbol{B} / \boldsymbol{C} / \boldsymbol{D}$ are differentiated by adding $10 / 20 / 30$ to the atom numbers of cation $\boldsymbol{A}$, respectively; the $\mathrm{O}$-atoms of water molecules are independently 
numbered as $\mathrm{O} 1 w, \mathrm{O} 2 w, \mathrm{O} 3 w$ and $\mathrm{O} 4 w$, where letter ' $w$ ' indicates the water molecule; the labels of $\mathrm{H}$-atoms are made of letter ' $\mathrm{H}$ ' and the number of the label of their carriers, and additionally numbered by letters ' $a$ ', ' $b$ ' and ' $c$ ' if required, while $\mathrm{H}$-atoms in water molecules are numbered by additional digits 1 and 2: all labels are shown explicitly in Fig. S1 in Supplementary Material. The crystal data, together with the details concerning data collection and structure refinement are given in Tables 1 and S1 (in the Supplementary Material). The crystal data have been deposited in the Cambridge Crystallographic Database Centre as Supplementary publications CCDC 1443312-1443323. Molecular illustrations were prepared using program Mercury CSD 3.3 [54].

FTIR spectrum of 1 was measured in the $\mathrm{KBr}$ disk using a Bruker IFS $66 \mathrm{v} / \mathrm{S}$ instrument, with the resolution of $2 \mathrm{~cm}^{-1}$. The spectra were accumulated of 64 scans.

The differential scanning calorimetry (DSC) of 1 was performed with a DSC THASS XP-10 calorimeter. The sample of $5.9 \mathrm{mg}$ was stored in an $\mathrm{Al}_{2} \mathrm{O}_{3}$ crucible in nitrogen atmosphere and the rate of temperature change was $5 \mathrm{~K} \mathrm{~min}^{-1}$.

Simultaneous TG-DTA curves were obtained with thermal analysis system model Setaram Setsys 1200 . The sample of $29.6 \mathrm{mg}$ was stored in an $\mathrm{Al}_{2} \mathrm{O}_{3}$ crucible in nitrogen atmosphere and the rate of temperature change was $5 \mathrm{~K} \mathrm{~min}^{-1}$

Elemental analysis was made using an Elemental Model Vario EL III instrument.

\section{DFT calculations}

The DFT calculations were performed with the GAUSSIAN 09 program package [55]. The calculations employed the B3LYP exchange-correlation functional, which combines the hybrid exchange functional of Becke $[56,57]$ with the gradient-correlation functional of Lee et al. [58] and the split-valence polarized 6-311++G(d,p) basis set [59]. The basis set for iodine has been taken from the EMSI Basis Set Library $[60,61]$ created by Glukhovtsev et al. [62]. The geometries of molecules determined by X-ray diffraction were used as the starting models for the structure optimizations. All

\begin{tabular}{lll}
\cline { 2 - 2 } $\begin{array}{l}\text { Table 1. Selected } \\
\text { crystal data of 3- } \\
\text { (trimethylammonium)- }\end{array}$ & Formula & {$\left[\mathrm{C}_{10} \mathrm{H}_{14} \mathrm{NO}_{2}\right]^{+} \cdot \mathrm{I}^{-} \cdot \mathrm{H}_{2} \mathrm{O}$} \\
benzoic acid iodide & Crystal system & monoclinic \\
hydrate at 296 K (cf. & Space group & $P c$ \\
Table S1 in the & $a(\AA)$ & $19.559(2)$ \\
Supplementary Material) & $b(\AA)$ & $7.7357(4)$ \\
& $c(\AA)$ & $19.689(2)$ \\
& $\beta\left({ }^{\circ}\right)$ & $118.50(2)$ \\
& Volume $\left(\AA^{3}\right)$ & $2618.0(3)$ \\
& $Z / Z$ & $8 / 4$ \\
& $D_{\mathrm{x}}\left(\mathrm{gcm}^{-3}\right)$ & 1.650 \\
\hline
\end{tabular}

calculated IR frequencies are real, consistently with the minimum energies of the optimized structures.

\section{Discussion}

\section{Crystal structure}

The crystal structure of 3-(trimethylammonium)-benzoic acid iodide hydrate is composed of the 3-(trimethylammonium)benzoic cation, iodide anion, and water molecules at the 1:1:1 ratio. This complex is remarkable in that it contains four independent formula units $\left(Z^{\prime}=4\right)$, as illustrated in Figs. 1 and 2.

The crystal symmetry is of monoclinic space group $P C$ (model I), but it approximates a higher symmetry of space group $P 2_{1} / c$ (model II), and even still higher symmetry $P 2_{1} /$ $c$ in the unit cell twice smaller along [x] (model III). This highly pseudosymmetric model III could be refined with anisotropic temperature factors to $R_{1}=0.0718$, but the water molecule appeared disordered in two positions and the thermal ellipsoids of the methyl were elongated ( $Z^{\prime}$ was equal to 1 for this pseudosymmetric model III); also the hydroxyl and carbonyl oxygen atoms of the carboxyl groups, as well as the carboxyl $\mathrm{H}$ atoms appeared disordered. The structure with the unit cell twice increased along $[\mathrm{x}]$ (as indicated by clearly observable, but considerably weaker reflections with odd $\mathrm{h}$ indices) still approximated the symmetry of space groups $P 2{ }_{1} / c$, with two symmetry-independent formula units $\left(Z^{\prime}=2\right)$. In this pseudosymmetric model II, the water molecules and the carboxyl groups became ordered, but one of independent cations had the methyls disordered. The $R_{1}$ factor for model II was 0.0637 . Because the systematic absences of the $2_{1}$ screw axes diverted slightly from zero intensities, we further reduced the model symmetry to space group $P c$, which increased $Z$ ' to 4 , and fully eliminated the conformational disorder (model I). This model refined to the lowest residue factors $\left(R_{1}=0.0594\right)$ and the lowest thermal displacement parameters. It also revealed subtle differences in the conformation of the carboxyl groups, as shown in Figs. 2 and 3, as well as the different orientations of trimethylammonium groups (Fig. 4).

According to the thermogravimetry (TG) measurements the compound 1 decomposes by losing water at $353 \mathrm{~K}$, and at still higher temperature a series of transitions take place in the anhydrate. No phase transition in hydrate I has been detected between 160-353 K (see the TG and DSC signals in Figs. S3 and S4).

The low temperature structural studies showed no transitions either, and confirmed that the crystal remained in the $P c$ symmetric phase with $Z^{\prime}=4$ down to $130 \mathrm{~K}$. Figure 5 shows the monotonic thermal expansion of the unit-cell parameters.

Four independent cations can be described as conformers due to different positions of trimethylammonium groups, as 
Fig. 2. Autostereographic projection [63] of the crystal structure of 1 , with the torsion angle C8-N1-C3-C2 indicated for 4 symmetry independent cations: letters $\mathbf{A}, \mathbf{B}, \mathbf{C}$ and $\mathbf{D}$ on the left side of the drawing indicate the rows of the independent cations along [z]. Pseudosymmetry elements have been indicated in yellow (screw axes $2_{1}$ ) and inversion centers (purple circles).

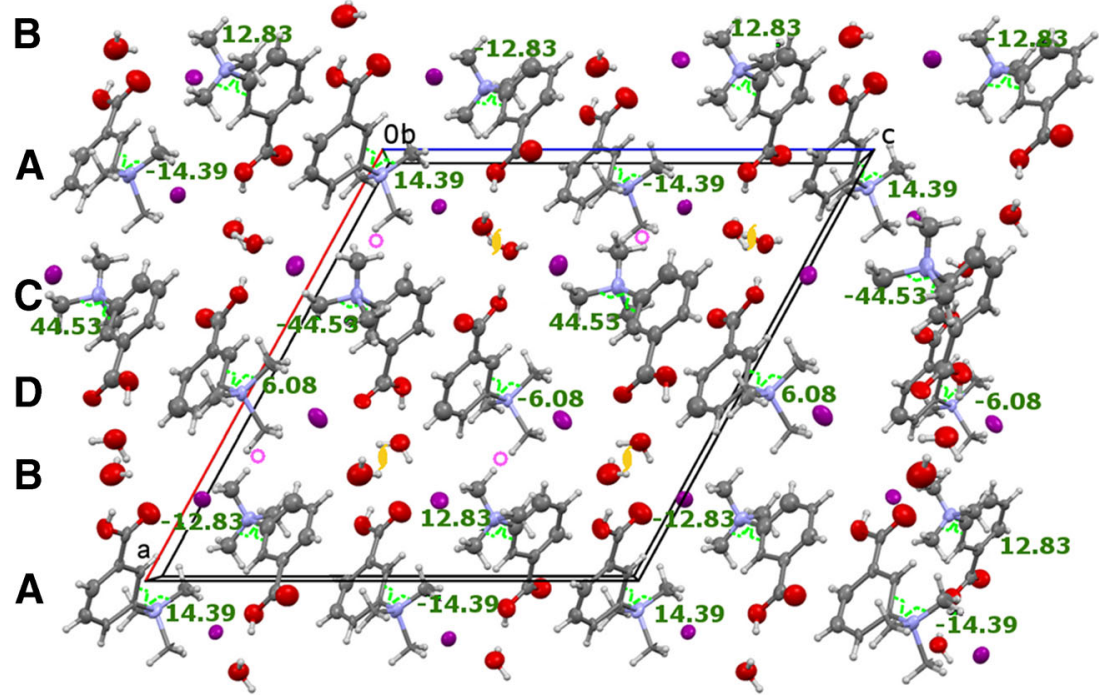

illustrated in Fig. 4. It can be observed that the positions of trimethylammonium groups in molecules $\boldsymbol{A}, \boldsymbol{B}$ and $\boldsymbol{D}$ are similar within about $10^{\circ}$ [i.e $(10 \pm 10)^{\circ}$ ], whereas the position of the group in molecule $\boldsymbol{C}$ is different by about $30^{\circ}$. The orientations of the trimethylammonium groups change within $10^{\circ}$ between 300 and $130 \mathrm{~K}$.

The carboxylic groups are bonded to the water molecule through the $\mathrm{O}(1)-\mathrm{H}(1) \cdots \mathrm{O}(1 \mathrm{~W}), \mathrm{O}(11)$ $\mathrm{H}(11) \cdots \mathrm{O}(2 \mathrm{~W}), \mathrm{O}(21)-\mathrm{H}(21) \cdots \mathrm{O}(3 \mathrm{~W})$ and $\mathrm{O}(31)-$ $\mathrm{H}(31) \cdots \mathrm{O}(4 \mathrm{~W})$ hydrogen bonds Table 2, cf. Tables S2). The iodide anions are located close to the positively charged trimethylammonium groups, and distances are $\mathrm{I}(1) \cdots \mathrm{N}(1) 4.393(9), \mathrm{I}(2) \cdots \mathrm{N}(2) 4.532(10), \mathrm{I}(3) \cdots \mathrm{N}(3)$ 4.639(9) and $\mathrm{I}(4) \cdots \mathrm{N}(4) 4.421(8) \AA$.

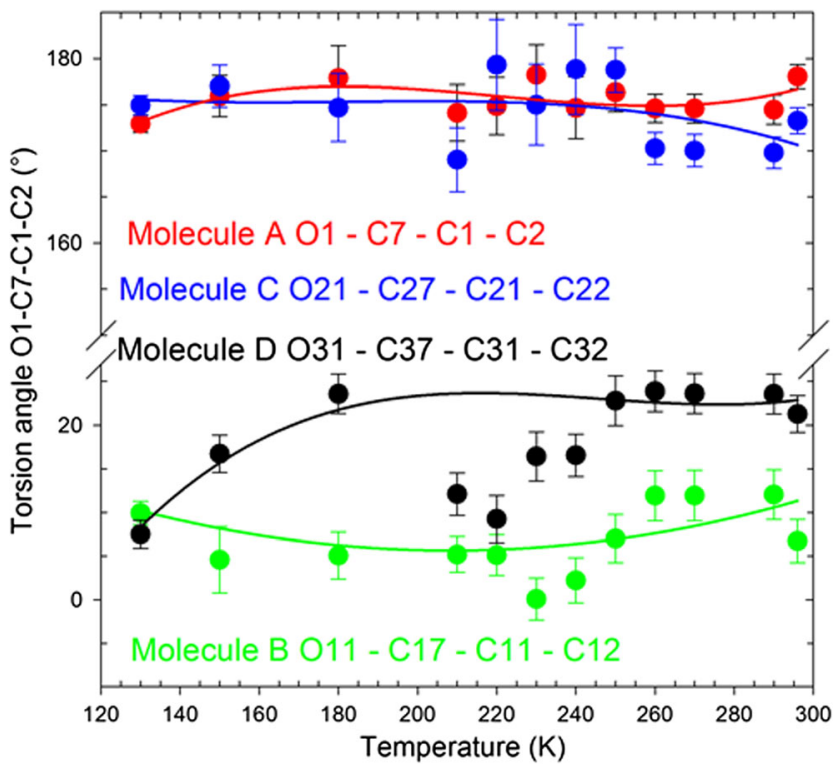

Fig. 3. Torsion angles O1-C7-C1-C2 in symmetry independent molecules $\mathbf{A}$ (red), $\mathbf{B}$ (green), $\mathbf{C}$ (blue) and $\mathbf{D}$ (black) in the structure of $\mathbf{1}$, as a function of temperature.

\section{DFT calculations}

The starting molecular geometries for theoretical computations were adopted of cations $\boldsymbol{A}$ and $\boldsymbol{B}$ with their closest $\mathrm{I}^{-}$ anions and water molecules. We have chosen the cations $\boldsymbol{A}$ and $\boldsymbol{B}$ for the calculations, because their conformation significantly differ in the position of the carboxyl group, whereas only minor differences in the positions of the trimethylammonium group is present in cations $\boldsymbol{C}$ and $\boldsymbol{D}$. These two structures have been optimized as models $2 A$ and $2 \boldsymbol{B}$ at the B3LYP/6-311++G(d,p) level of theory. As can be seen in the drawings of two optimized models $2 \boldsymbol{A}$ and $2 \boldsymbol{B}$, shown in Fig. 6, their conformations well reproduce the opposite orientation of the carboxyl groups, this in cations $\boldsymbol{A}$ and

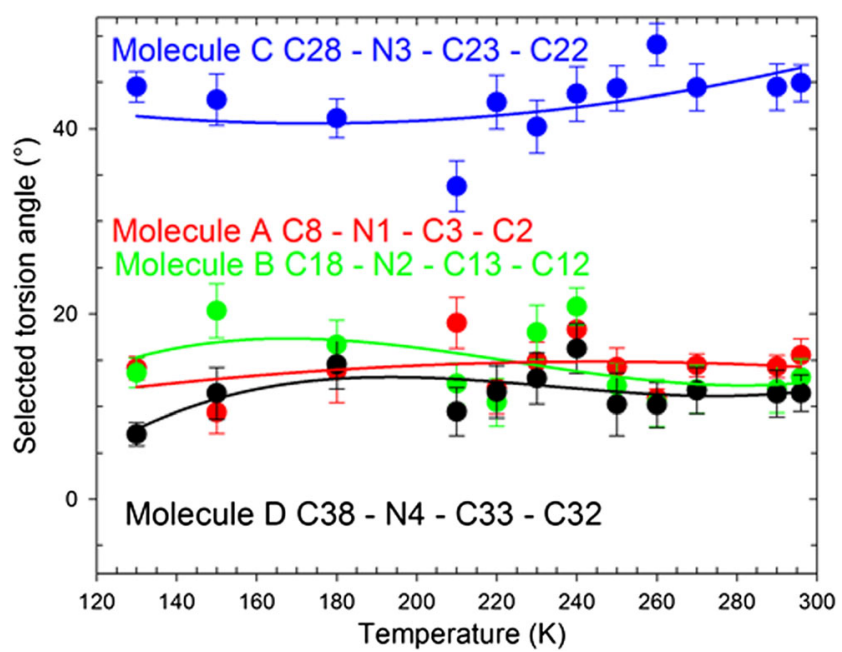

Fig. 4. Torsion angles C8-N1-C3-C2 describing the orientation of trimethylammonium groups in symmetry independent molecules $\mathbf{A}$ (red), $\mathbf{B}$ (green), $\mathbf{C}$ (blue) and $\mathbf{D}$ (black) in the structure of $\mathbf{1}$, as a function of temperature. The magnitudes for molecules $\mathbf{B}$ and $\mathbf{C}$ have been transformed to the positive values. 


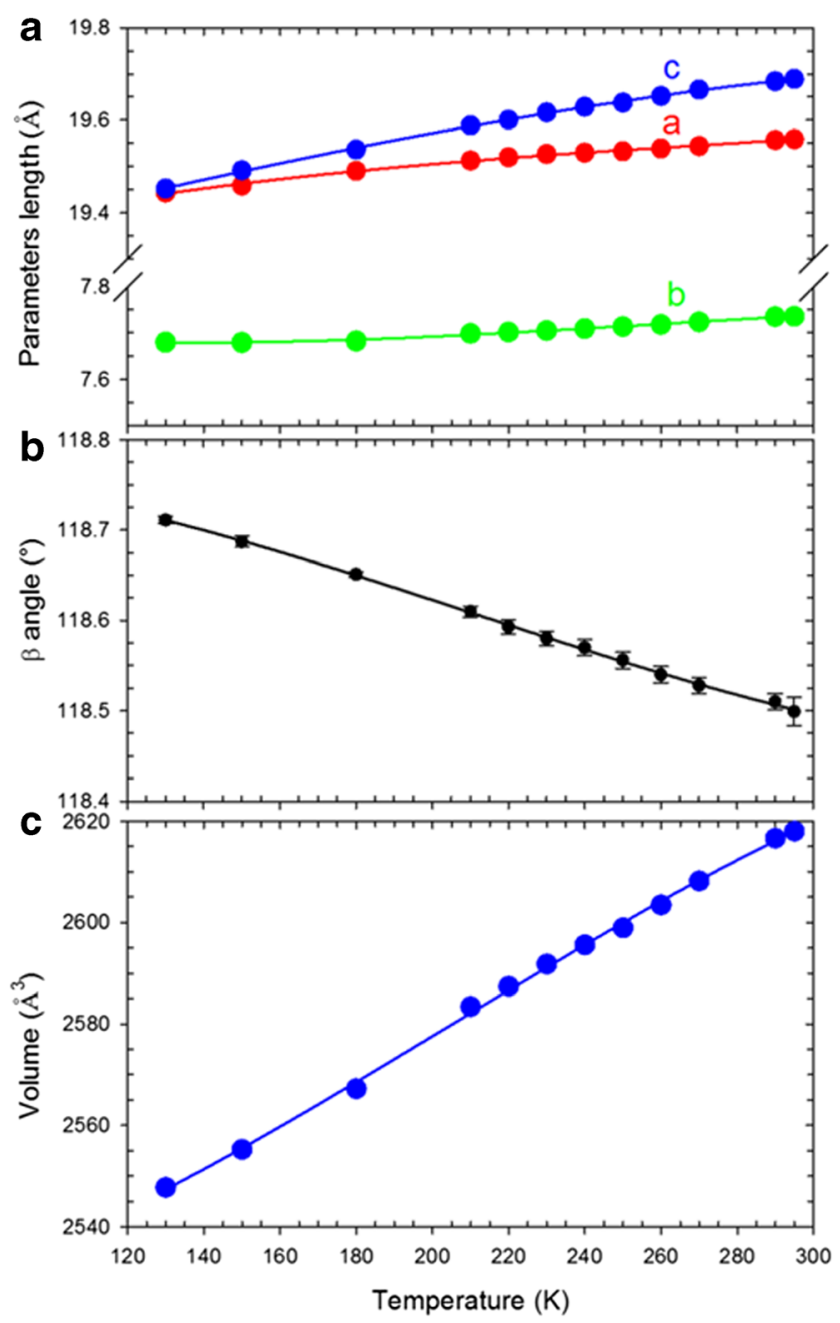

Fig. 5. Unit-cell dimensions of 1 plotted as a function of temperature: (a) parameters $a, b$ and $c$; (b) angle $\beta$ and (c) the unit-cell volume. The estimated standard deviations are smaller than the symbols.

$\boldsymbol{C}$ versus that in cations $\boldsymbol{B}$ and $\boldsymbol{D}$. It is thus apparent that both conformations of the carboxyl group are very similar energetically and therefore they both can be present in the crystal structure. On the other hand it shows that the conformational differentiation is advantageous for the crystal packing.

The optimized structures well represent the crystal ones. The $\mathrm{O}(1)-\mathrm{H}(1) \cdots \mathrm{O}(1 \mathrm{~W})$ hydrogen bond is slightly shorter in $2 \boldsymbol{B}$ than in $\mathbf{2 A}$, similarly as in the crystal (Table 2). The calculated energies are $\mathrm{E}(\mathrm{a} . \mathrm{u})=-7590.8511393$ and dipole moment $\mu=16.18 \mathrm{D}$ for $2 A$, and $\mathrm{E}(\mathrm{a} . \mathrm{u})=-7590.8508038$ and dipole moment $\mu=15.87 \mathrm{D}$ for $2 \boldsymbol{B}$. The energy of structure $2 \boldsymbol{A}$ is lower by $0.88 \mathrm{KJ} / \mathrm{mol}$ than that of structure $\boldsymbol{2 B}$. The optimized structures differ significantly in the orientation of the carboxylic group and slightly in the $\mathrm{N}^{+} \cdots \mathrm{I}^{-}$distances, which are 4.082 in $2 A$ and $4.092 \AA$ in $2 B$. The torsion angles O1-C7C1-C2 and C8-N1-C3-C2 describing the orientations of the carboxyl and trimethylammonium groups are 179.90 and $0.24^{\circ}$ in model $2 \mathrm{~A}$ and 0.09 and $0.11^{\circ}$ in model $2 \boldsymbol{B}$, respectively (cf. Figs 3 and 4).
Table 2. Experimental (1-model I) and calculated 2A and $\mathbf{2 B}$ by the B3LYP/6-311++G(d,p) approach, selected dimensions of hydrogen bonds and short contacts for 3-(trimethylammonium)-benzoic acid iodide hydrate $\left(\AA\right.$ and $\left.^{\circ}\right)$ at $296 \mathrm{~K}$ (cf. Table S2 in Supplementary Material)

\begin{tabular}{|c|c|c|c|c|}
\hline & $\mathrm{D}-\mathrm{H} \cdots \mathrm{A}$ & $\mathrm{H} \cdots \mathrm{A}$ & $\mathrm{D} \cdots \mathrm{A}$ & $\mathrm{DH} \cdots \mathrm{A}$ \\
\hline \multirow[t]{14}{*}{ 1-I } & $\mathrm{O}(1)-\mathrm{H}(1) \cdots \mathrm{O}(1 \mathrm{~W})$ & $1.679(8)$ & $2.487(12)$ & $167.8(8)$ \\
\hline & $\mathrm{O}(11)-\mathrm{H}(11) \cdots \mathrm{O}(2 \mathrm{~W})$ & $1.798(15)$ & $2.615(18)$ & $174.4(11)$ \\
\hline & $\mathrm{O}(21)-\mathrm{H}(21) \cdots \mathrm{O}(3 \mathrm{~W})$ & $1.967(8)$ & $2.729(11)$ & $154.2(3)$ \\
\hline & $\mathrm{O}(31)-\mathrm{H}(31) \cdots \mathrm{O}(4 \mathrm{~W})$ & $1.816(8)$ & $2.630(12)$ & $171.8(8)$ \\
\hline & $\mathrm{O}(1 \mathrm{~W})-\mathrm{H}(11 \mathrm{~W}) \cdots \mathrm{I}(2)$ & $2.9999(10)$ & $3.622(10)$ & 131.1(6) \\
\hline & $\mathrm{O}(1 \mathrm{~W})-\mathrm{H}(21 \mathrm{~W})^{\mathrm{i} \cdots \mathrm{I}(4)}$ & $2.9803(9)$ & $3.736(7)$ & $148.2(8)$ \\
\hline & $\mathrm{O}(2 \mathrm{~W})-\mathrm{H}(12 \mathrm{~W})^{\mathrm{ii} \ldots \mathrm{I}(3)}$ & $2.8689(11)$ & $3.586(11)$ & $142.3(12)$ \\
\hline & $\mathrm{O}(2 \mathrm{~W})-\mathrm{H}(22 \mathrm{~W}) \cdots \mathrm{I}(1)$ & $3.0024(9)$ & $3.521(14)$ & $120.9(10)$ \\
\hline & $\mathrm{O}(3 \mathrm{~W})-\mathrm{H}(13 \mathrm{~W})^{\mathrm{iii} \cdots \mathrm{I}(2)}$ & $3.0110(8)$ & $3.785(7)$ & 151.1(8) \\
\hline & 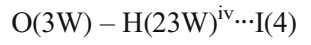 & $2.784(1)$ & $3.568(11)$ & $152.7(6)$ \\
\hline & $\mathrm{O}(4 \mathrm{~W})-\mathrm{H}(24 \mathrm{~W}) \cdots \mathrm{I}(1)$ & $2.9166(11)$ & $3.526(7)$ & $129.6(6)$ \\
\hline & $\mathrm{O}(4 \mathrm{~W})-\mathrm{H}(14 \mathrm{~W})^{\mathrm{v} \cdots \mathrm{I}(3)}$ & $2.7583(8)$ & $3.587(7)$ & $163.2(4)$ \\
\hline & $\mathrm{O}(22) \cdots \mathrm{O}(1 \mathrm{~W})^{\mathrm{vi}}$ & & $2.964(13)$ & \\
\hline & $\mathrm{O}(2) \cdots \mathrm{O}(3 \mathrm{~W})^{\mathrm{vii}}$ & & $3.027(12)$ & \\
\hline $2 \mathrm{~A}$ & $\mathrm{O}(1)-\mathrm{H}(1) \cdots \mathrm{O}(1 \mathrm{~W})$ & 1.702 & 2.662 & 160.58 \\
\hline 2B & $\mathrm{O}(1)-\mathrm{H}(1) \cdots \mathrm{O}(1 \mathrm{~W})$ & 1.700 & 2.660 & 160.33 \\
\hline
\end{tabular}

Symmetry codes: (i) $=1+\mathrm{x}, \mathrm{y}, 1+\mathrm{z}$; (ii) $=\mathrm{x}, 2-\mathrm{y},-0.5+\mathrm{z}$; (iii) $=-1+\mathrm{x}, 2-\mathrm{y}$,$0.5+\mathrm{z}$; (iv) $=\mathrm{x}, 3-\mathrm{y}, 0.5+\mathrm{z} ;(\mathrm{v})=\mathrm{x}, 1-\mathrm{y},-0.5+\mathrm{z} ;(\mathrm{vi})=1+\mathrm{x}, 2-\mathrm{y}, 0.5+\mathrm{z}$; (vii) $=-1+\mathrm{x}, 3-\mathrm{y},-0.5+\mathrm{z}$

\section{FTIR spectrum}

The solid-state spectrum of 3-(trimethylammonium)-benzoic acid iodide hydrate shown in Fig. 7 is consistent with the structure of 1 . The band at $3447 \mathrm{~cm}^{-1}$ with a shoulder at $3555 \mathrm{~cm}^{-1}$ is attributed to the stretching vibration $\mathrm{O}(1 \mathrm{~W})-$ $\mathrm{H}(\mathrm{W})$ of water molecule. The broad absorption in the 3000$2000 \mathrm{~cm}^{-1}$ region is attributed to the $v \mathrm{O}(1)-\mathrm{H}(1) \cdots \mathrm{O}(1 \mathrm{~W})$ hydrogen bond vibration. It is typical for $\mathrm{O}-\mathrm{H} \cdots \mathrm{O}$ hydrogen bond of the length of $c a .2 .6 \AA$. The splitting band at 1722 and $1704 \mathrm{~cm}^{-1}$ can be assigned to $\mathrm{VCO}$ modes in independent cations, while the intensive band at $1258 \mathrm{~cm}^{-1}$ to the $\delta \mathrm{CO}$ and $\delta \mathrm{OH}$ vibrations.

The calculated IR spectra of $2 A$ and $2 B$, in vertical lines, are shown in Fig. $7 \mathrm{~b}$ (the spectrum of $2 A$ in black line and $2 B$ in red line). The differences between the calculated and
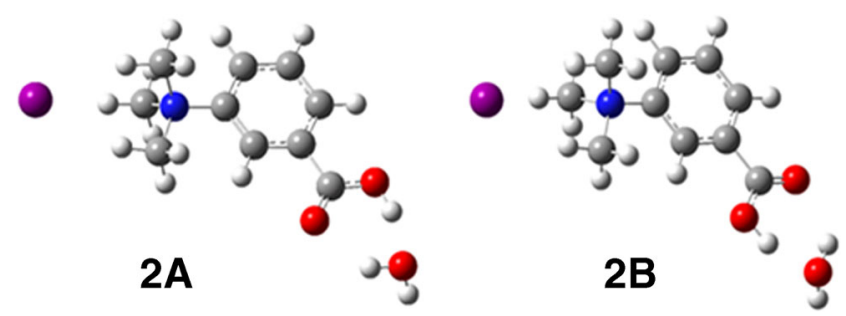

Fig. 6. Computed structures of $\mathbf{2 A}$ and $\mathbf{2 B}$ of 3-(trimethylammonium)benzoic acid iodide hydrate 


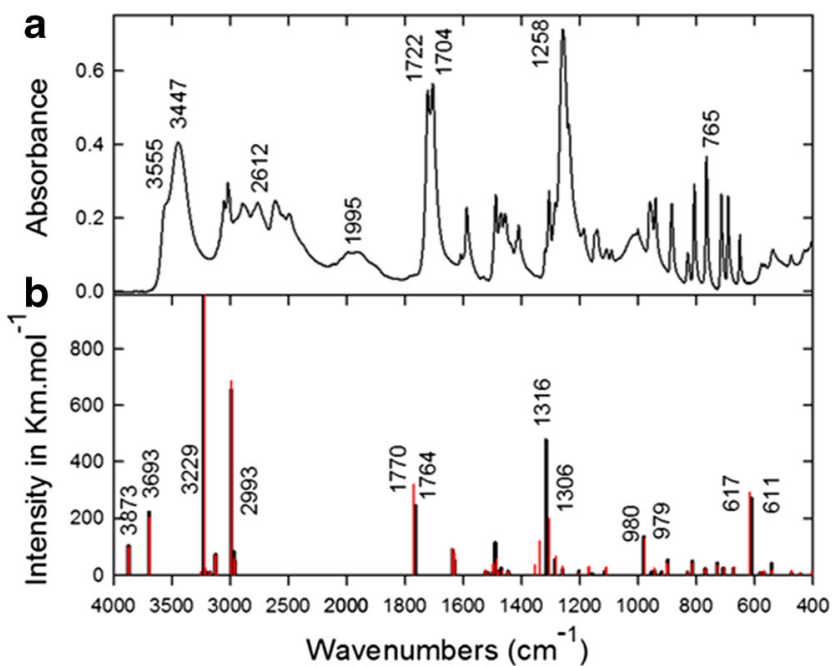

Fig. 7. (a) The solid-state FTIR spectrum of 3-(trimethylammonium)benzoic acid iodide hydrate (1) and (b) the calculated, by the B3LYP/6$311++\mathrm{G}(\mathrm{d}, \mathrm{p})$ approach, spectra of $\mathbf{2 A}$ (black line) and $\mathbf{2 B}$ (red line).

experimental frequencies follow from the fact that the experimental spectrum was recorded for the compound in solid state, while the computations were made for the vibrations of isolated molecule in gas phase. The calculated bands are shifted to higher wavenumbers relative to the experimental data, because the calculations are based on harmonic frequency, while the experimental ones are based on the anharmonic frequencies. In the computed theoretically IR spectra of $2 A$ and $2 \boldsymbol{B}$ optimized structures the $\nu_{\mathrm{as}} \mathrm{O}(1 \mathrm{~W})-\mathrm{H}(\mathrm{W})$ and $\nu_{\mathrm{s}} \mathrm{O}(1 \mathrm{~W})-\mathrm{H}(\mathrm{W})$ bands are predicted at 3872 and $3696 \mathrm{~cm}^{-1}$, respectively. The $v \mathrm{O}(1)-\mathrm{H}(1)$ mode is predicted at $3223 \mathrm{~cm}^{-1}$ in both spectra. The differences in the spectra of $2 A$ and $2 B$ are observed in the carboxylic group region. The $\gamma \mathrm{CO}, \delta \mathrm{CO}$ and $\delta \mathrm{OH}$ vibrations are calculated at 1764 and $1315 \mathrm{~cm}^{-1}$, respectively for $2 A$, whereas at 1770 and $1306 \mathrm{~cm}^{-1}$, respectively for $2 B$. The bands at 980 and $978 \mathrm{~cm}^{-1}$ are predicted to the $\gamma \mathrm{O}(1)-$ $\mathrm{H}(1)$ vibrations in the spectra of $\boldsymbol{2 A}$ and $2 \boldsymbol{B}$. The band at $611 \mathrm{~cm}^{-1}$ is calculated for $\gamma \mathrm{O}(1 \mathrm{~W})-\mathrm{H}(\mathrm{W})$ mode.

\section{Conclusions}

The high pseudosymmetry of crystal 1 can be attributed to the conformational freedom in the cations, where two opposite orientations of the carboxyl groups hardly change the potential energy of the cation. It discriminates the cations and also affects the positions of $\mathrm{H}$-bonded water molecules. However the origin of further differentiation of the cations, by the orientations of trimethylammonium groups remains puzzling, particularly that this soft conformational parameter breaks the symmetry of inversion center. In the terms of crystal engineering, such a change could be most required for producing noncentrosymmetric crystals for second harmonic generation and other applications. It occurred that the crystals of 1 are quite stable and no transitions to any of higher-symmetric models II and III (both centrosymmetric) could be detected. It testifies that the factors differentiating the conformers are significant and their identification would significantly contribute to understanding of the rules governing the symmetry of molecules crystals.

Open Access This article is distributed under the terms of the Creative Commons Attribution 4.0 International License (http:// creativecommons.org/licenses/by/4.0/), which permits unrestricted use, distribution, and reproduction in any medium, provided you give appropriate credit to the original author(s) and the source, provide a link to the Creative Commons license, and indicate if changes were made.

\section{References}

1. Domingo X (1996) In: Lomax EG (ed) Amphoteric surfactants. Marcel Dekker, New York, pp. 76-190

2. Schmidt A (2003) Adv Heterocycl Chem 85:67-171

3. Alcalde E (1994) Adv Heterocycl Chem 60:197-259

4. Jones RA (2001) Quaternary ammonium salts. Academic Press, San Diego

5. Laughlin RG (1991) Langmuir 7:842-847

6. Szafran M, Katrusiak A, Dega-Szafran Z, Dymarska S, GrundwaldWyspiańska M (2002) J Mol Struct 609:19-28

7. Szafran M, Katrusiak A, Kowalczyk I, Dega-Szafran Z, Drozd M (2004) J Mol Struct 689:213-222

8. Szafran M, Dega-Szafran Z, Grundwald-Wyspiańska M, Barczyński P, Pankowski M (2002) Pol J Chem 76:1191-1197

9. Szafran M, Katrusiak A, Koput J, Dega-Szafran Z (2004) J Mol Struct 704:45-52

10. Szafran M, Katrusiak A, Dega-Szafran Z, Kowalczyk I (2013) J Mol Struct 1031:49-55

11. Szafran M, Ostrowska K, Katrusiak A, Dega-Szafran Z (2014) Spectrochim Acta A 128:844-851

12. Chen XM, Mak TCW (1990) J Mol Struct 221:265-269

13. Chen XM, Mak TCW (1990) J Mol Struct 240:69-75

14. Szafran M, Katrusiak A, Dega-Szafran Z (2006) J Mol Struct 794: 46-53

15. Szafran M, Katrusiak A, Koput J, Dega-Szafran Z (2006) J Mol Struct 784:98-108

16. Szafran M, Katrusiak A, Dega-Szafran Z (2007) J Mol Struct 827: 56-66

17. Komasa A, Katrusiak A, Kaźmierczak M, Dega-Szafran Z, Szafran M (2015) Spectrochim Acta A 136:1149-1156

18. Jiyang W, Gnanam FD, Haussühl S (1986) Z Kristallogr 175:155158

19. Huang W-Y, Du X-M, Yang B-H, Mak TCW (1990) J Mol Struct 222:479-485

20. Beja AM, Taixão JA, Silva MR, da Veige LA (2000) Z Kristallogr 215:581-582

21. Ilczyszyn M, Godzisz D, Ilczyszyn MM (2002) J Mol Struct 611: 103-118

22. Szafran M, Kowalczyk I, Katrusiak A, Dega-Szafran Z (2003) J Mol Struct 651-653:621-634

23. Dega-Szafran Z, Katrusiak A, Szafran M, Barczyński P (2010) J Mol Struct 975:357-366

24. Dega-Szafran Z, Katrusiak A, Szafran M (2010) J Mol Struct 971: 53-61

25. Baran J, Drozd M, Lis T, Śledź M, Barnes AJ, Ratajczak H (1995) J Mol Struct 372:29-40 
26. Barczyński P, Komasa A, Katrusiak A, Dega-Szafran Z, Szafran M (2007) J Mol Struct 832:63-72

27. Kowalczyk I, Katrusiak A, Szafran M, Dega-Szafran Z (2012) J Mol Struct 1026:150-158

28. Barczyński P, Katrusiak A, Koput J, Dega-Szafran Z, Szafran M (2009) J Mol Struct 918:39-54

29. Haussühl S, Jiyang W (1989) Z Kristallogr 187:249-251

30. Dörffel M, Narz T, Haussühl S (1989) Z Kristallogr 186:71-73

31. Alberts J (1988) Ferroelectrics 78:3-10

32. Zobetz E, Preisinger A (1989) Monatsch Chem 120:291-298

33. Maeda M (1988) J Phys Soc Jpn 57:2162-2167

34. Schaack G (1990) Ferroelectrics 104:147-158

35. Baran J, Lis T, Pietraszko A, Ratajczak H (1993) Bull Pol Acad Sci Chem 41:235-241

36. Ilczyszyn MM, Ratajczak H (1996) J Mol Struct 375:23-35

37. Baran J, Dega-Szafran Z, Jaskólski M, Marchewka MK, Ratajczak H, Szafran M (1997) J Mol Struct 406:127-135

38. Góśniowska M, Cunik Z, Bator G, Jakubas R (1999) J Mol Struct 511-512:345-354

39. Nyrönen TH, Suontamo R, Pitkänen I (1999) Theor Chem Accounts 101:209-214

40. Ilczyszyn MM (2000) J Mol Struct 519:257-274

41. Ilczyszyn MM (2000) J Mol Struct 519:275-296

42. Tadros W, Sakla AB (1954) J Chem Soc 1116-1119

43. Kosower EM, Patton JW (1961) J Org Chem 26:1318-1319

44. Edsall JT, Wyman Jr J (1935) J Am Chem Soc 57:1964-1975

45. Hojo M, Utaka M, Yoshida Z (1971) Tetrahedron 27:4255-4262

46. Picha J, Cibulka R, Liška F, Pařik P, Pytela O (2004) Collect Czechoslov Chem Commun 69:2239-2252

47. Szafran M, Katrusiak A, Dega-Szafran Z, Kowalczyk I (2011) J Mol Struct 996:75-81

48. Szafran M, Katrusiak A, Dega-Szafran Z, Kowalczyk I (2011) J Mol Struct 1005:144-151

49. Szafran M, Katrusiak A, Dega-Szafran Z, Kowalczyk I, Komasa A (2011) J Mol Struct 1006:330-336
50. Szafran M, Katrusiak A, Kowalczyk I, Komasa A, Dega-Szafran Z (2012) J Mol Struct 1017:115-122

51. Wood GW, Collacott RJ (1983) Org Mass Spectrom 18:42-45

52. Ostrowska K, Kowalczyk I, Kaźmierczak M, Katrusiak A, Szafran M, Komasa A, Dega-Szafran Z (2015) Cryst EngComm 17:41434149

53. Sheldrick GM (2008) Acta Crystallogr A 64:112-122

54. Macrae CF, Edgington PR, McCabe P, Pidcock E, Shields GP, Taylor R, Towler M, van de Streek J (2006) J Appl Crystallogr 39:453-457

55. Frisch MJ, Trucks GW, Schlegel HB, Scuseria GE, Robb MA, Cheeseman JR, Scalmani G, Barone V, Mennucci B, Petersson GA, Nakatsuji H, Caricato M, Li X, Hratchian HP, Izmaylov AF, Bloino J, Zheng G, Sonnenberg JL, Hada M, Ehara M, Toyota K, Fukuda R, Hasegawa J, Ishida M, Nakajima T, Honda Y, Kitao O, Nakai H, Vreven T, Montgomery JA, Peralta JE, Ogliaro F, Bearpark M, Heyd JJ, Brothers E, Kudin KN, Staroverov VN, Keith T, Kobayashi R, Normand J, Raghavachari K, Rendell A, Burant JC, Iyengar SS, Tomasi J, Cossi M, Rega N, Millam JM, Klene M, Knox JE, Cross JB, Bakken V, Adamo C, Jaramillo J, Gomperts R, Stratmann RE, Yazyev O, Austin AJ, Cammi R, Pomelli C, Ochterski JW, Martin RL, Morokuma K, Zakrzewski VG, Voth GA, Salvador P, Dannenberg JJ, Dapprich S, Daniels AD, Farkas O, Foresman JB, Ortiz JV, Cioslowski J, Fox DJ (2010) GAUSSIAN 09, Revision B.01. Gaussian Inc, Wallingford

56. Becke AD (1993) J Chem Phys 98:5648-5652

57. Becke AD (1997) J Chem Phys 107:8554-8560

58. Lee C, Yang W, Parr GR (1988) Phys Rev B 37:785-789

59. Hehre WJ, Radom L, Schleyer PvR, Pople JA (1986) Ab initio molecular orbital theory. Wiley, New York

60. Feller D (1996) J Comp Chem 17:1571-1586

61. Schuchardt LL, Didler BT, Eisethagen T, Sun L, Gurumoorthi V, Chase J, Li J, Windus TL (2007) J Chem Inf Model 47:1045-1052

62. Glukhovtsev MN, Pross A, McGrath MP, Radom L (1995) J Chem Phys 103:1878-1885

63. Katrusiak A (2001) J Mol Graph Modell 19:363-367 